\title{
Cloning and expression of haloacid dehalogenase gene from Bacillus cereus IndB1
}

\author{
Enny Ratnaningsih ${ }^{1}$ and Idris ${ }^{2, *}$ \\ ${ }^{1}$ Biochemistry Research Division, Department of Chemistry, Faculty of Mathematics and Natural Sciences, Institut Teknologi Bandung, \\ Jalan Ganesha 10, Bandung 40132, Indonesia \\ ${ }^{2}$ Universitas Islam Negeri Sultan Maulana Hasanuddin Banten, Jalan Jend. Sudirman No. 30 Serang, Banten 42118, Indonesia \\ *Corresponding author: mynameidris@gmail.com
}

\begin{abstract}
Organohalogen compounds, widely used as pesticides in agriculture and solvents in the industrial sector, cause environmental pollution and health problems due to their toxicity and persistence. Numerous studies have been conducted on the biodegradation of organohalogen compounds, with many focusing on the use of dehalogenase from bacteria. Haloacid dehalogenase is a group of enzymes that cleaves the carbon-halogen bond in halogenated aliphatic acids. In a previous study, the $b c f d 1$ gene encoded haloacid dehalogenase from Bacillus cereus IndB1 was successfully isolated and characterized. This research aimed to create an expression system of the $b c f d 1$ gene by subcloning this gene into $\mathrm{pET}$ expression vector and to overexpress the gene in Escherichia coli BL21 (DE3). In addition, the recombinant protein was characterized to gain a better understanding of the catalytic action of this enzyme. A high expression of bcfd1 was obtained by inducing the culture at $\mathrm{OD}_{550}$ 0.8-1.0 using 0.01 mM IPTG as determined by SDS-PAGE. Zymogram analysis proved that the recombinant protein possessed dehalogenase activity. Bcfd1 activity toward monochloroacetic acid (MCA) showed specific activity of $37 \mathrm{U} / \mathrm{mg}$ at $30^{\circ} \mathrm{C}, \mathrm{pH}$ 9. The predicted tertiary structure of Bcfd1 was estimated has conserved $\alpha / \beta$ hydrolase folding motif for haloacid dehalogenase superfamily.
\end{abstract}

KEYWORDS Bacillus cereus IndB1; bcfd1 gene; heterologous expression; haloacid dehalogenase; organohalogen

\section{Introduction}

Organohalogen compounds are organic compounds that are widely used as pesticides, plasticizers, precursors, and solvents in several industries. These compounds are xenobiotic and can cause environmental pollution and health problems because of their toxicity, persistence, and ability to transform into other hazardous metabolites (Huyop et al. 2004).

Organohalogen compounds are one of the biggest pollutants in the hydrosphere (Römpp et al. 2001). Biodegradation using microorganisms has been considered an environmentally friendly and economical method of handling organohalogen pollutants as these microorganisms can metabolize and transform organohalogen compounds to make them non-toxic (Maier et al. 2009). To this end, a number of microorganisms with dehalogenase activity have been isolated and characterized, such as Moraxella sp. (Kawasaki et al. 1992), Pseudomonas sp. (Liu et al. 1994), Bulchordia sp. (Tsang and Sam 1999), Rhizobium sp. (Huyop et al. 2004), Bacillus sp. (Olaniran et al. 2004), Xanthobacter sp. (Torz and Beschkov 2005), and Rhodobacteraceae sp. (Novak et al. 2013).
Haloacid dehalogenases are a group of hydrolase class enzymes that break the carbon-halogen bond in halogenated aliphatic acids (Hardman and Slater 1981), and are classified into two major classes, DehI and DehII (Hill et al. 1999). DehI is a L-haloacid dehalogenase that only works at L-enantiomer substrate, whereas DehII consists of two kinds of enzymes, D-haloacid dehalogenase which only works at D-enantiomer substrate, and DL-haloacid dehalogenase which can work at both enantiomer forms.

The development of recombinant DNA technology allows enzyme production in large quantities with similar properties to the native form (Cohen et al. 1973; Choi et al. 2006). A previous study successfully isolated and characterized the $b c f d 1$ gene that encoded dehalogenase enzyme from Bacillus cereus IndB1 obtained from the Indonesian Agriculture Research and Development Association (Arif 2013). This research aimed to create an expression system of the haloacid dehalogenase gene from $B$. cereus IndB1 by subcloning the gene into the $\mathrm{pET}$ expression vector in Escherichia coli BL21 (DE3). Further research in characterizing its protein activity will also be performed through in silico and in vitro analysis to gain a better understanding of the catalytic activity of this enzyme. 


\section{Materials and methods}

\subsection{Bacterial strains and chemicals}

B. cereus IndB1 obtained from the Agriculture Research and Development Association of Indonesia was used as a chromosomal DNA source. E. coli TOP 10 was used as a host cell in the cloning process and E. coli BL21(DE3) was used as a host cell in gene expression. Two kinds of plasmids were used in this study, namely pGEM-T Easy (Promega, United States) and pET-30a(+). pGEM$\mathrm{T}$ Easy was used as a cloning vector and pET-30a $(+)$ was used as an expression vector. The genomic DNA of $B$. cereus IndB1 was isolated using a DNA extraction kit from Qiagen (Germany). Restriction endonucleases (EcoRI and HindIII), T4 DNA ligase and DNA ladder $1 \mathrm{~kb}$ were purchased from Promega. Oligonucleotide primers for amplification of haloacid dehalogenase gene were designed manually and ordered from 1stBASE (Malaysia). Monochloro acetic acid (MCA) was purchased from Merck (United States). Isopropyl-this-ßD-galactoside (IPTG) was used to induce the gene expression under control of lac promoter. All the chemicals used in this work were analytical grade.

\subsection{Construction of dehalogenase gene expression}

A pair of primers was designed based on nucleotide sequences of the haloacid dehalogenase gene from $B$. cereus IndB1 named bcfd1 (Arif 2013). This gene has been submitted to GenBank with Accession Number KU498039. The designed primers were 5'-GCAGAATTCATGGATGGAACACTACTATC-3' as the forward primer and 5'-GCGAAGCTTTTATTTACTAGATGAAGTTTG-3' as the reverse primer. The underline sequences indicate the EcoRI and HindIII recognition sites, respectively.

DNA amplification was performed using the KAPA Taq ReadyMix PCR kit (Kapa Biosystems) with the genomic DNA of $B$. cereus strain IndB1 serving as a template. The PCR reaction of $20 \mu \mathrm{L}$ was prepared using KAPA Taq ReadyMix in accordance with the KAPA Taq PCR protocol. PCR reaction was initiated with predenaturation at $94^{\circ} \mathrm{C}$ for $4 \mathrm{~min}$, followed by 34 cycles of denaturation at $94^{\circ} \mathrm{C}$ for $15 \mathrm{~s}$, annealing at $52^{\circ} \mathrm{C}$ for $30 \mathrm{~s}$, and extension at $72^{\circ} \mathrm{C}$ for $1 \mathrm{~min}$. The reaction was completed by a final extension at $72^{\circ} \mathrm{C}$ for $5 \mathrm{~min}$. The obtained amplicon was confirmed by electrophoresis on a $1 \% \mathrm{w} / \mathrm{v}$ agarose gel.

The amplicon was first cloned into pGEM-T Easy vector then subcloned into pET-30a(+) expression vector. Recombinant pGEM-bcfd1 was digested with EcoRI and HindIII, ligated into linear pET-30a(+), transformed into E. coli BL21 (DE3) and grown on kanamycin selection medium. The pET-bcfd1 recombinant clone was isolated and confirmed by the size screening, re-PCR, restriction analysis and sequencing.

\subsection{Expression of recombinant protein}

E. coli BL21 (DE3) carrying pET-bcfd1 was grown in liquid LB media supplemented with $50 \mu \mathrm{g} / \mathrm{ml}$ kanamycin at $37^{\circ} \mathrm{C}$ to reached $0.8-1.0$ of $\mathrm{OD}_{550}$ and induced with 0.01 $\mathrm{mM}$ IPTG for protein expression and further incubated at $30^{\circ} \mathrm{C}$ for $2-4 \mathrm{~h}$. The crude extract recombinant protein was prepared from the cells taken every hour from the culture. The cells were harvested by centrifugation, washed with $50 \mathrm{mM}$ Tris-acetate ( $\mathrm{pH}$ 7.5), lysed by sonication for $20 \mathrm{~min}$, and the crude extract was separated from the cell debris by centrifugation.

\subsection{Preparation of crude extract protein}

The crude extract was prepared by collecting cells from a culture that was induced for $2 \mathrm{~h}$ by centrifugation at $9820 \mathrm{xg}$ for $20 \mathrm{~min}$ at $4^{\circ} \mathrm{C}$. The supernatant was disposed and the cell pellet was washed with $50 \mathrm{mM}$ Tris-acetate, pH 7.5 buffer twice. The cell pellet was resuspended in the same buffer and lysed by sonicating on ice for $20 \mathrm{~min}$ with intervals $30 \mathrm{~s}$ on/ $30 \mathrm{~s}$ off. The cell debris was separated from the supernatant by centrifugation at $6000 \mathrm{x}$ textitg for $30 \mathrm{~min}, 4^{\circ} \mathrm{C}$. The supernatant is crude extract recombinant protein and immediately used for activity assay.

\subsection{Protein expression analysis with SDS-PAGE}

The crude extract recombinant protein was loaded on $12 \%$ SDS-PAGE to confirm the protein expression. The protein was visualized by staining the gel in a Coomassie brilliant blue solution while a protein ladder was used as the size standard.

\subsection{Qualitative assay of haloacid dehalogenase activ- ity}

Haloacid dehalogenase activity was qualitatively analyzed through native-polyacrylamide gel electrophoresis (Hardman and Slater 1981). The gel was incubated at $30^{\circ} \mathrm{C}$ in $100 \mathrm{mM}$ Tris-acetate buffer $\mathrm{pH} 9$ containing $50 \mathrm{mM}$ monochloroacetic acid (MCA) for $30 \mathrm{~min}$. Dehalogenase activity was detected after further incubation in $0.1 \mathrm{M}$ $\mathrm{AgNO}_{3}$ solution. The white precipitate of $\mathrm{AgCl}$ on the gel around protein band indicated positive dehalogenase activity.

\subsection{Quantitative assay of haloacid dehalogenase ac- tivity}

Haloacid dehalogenase activity was quantitatively determined using colorimetry method by measuring released chloride ion concentration (Bergmann and Sanik 1957). The enzymatic reaction was performed in $1 \mathrm{~mL}$ solution containing $50 \mu \mathrm{L}$ of crude extract and $5 \mathrm{mM}$ MCA. The reaction mixture was incubated at various $\mathrm{pH}$ and temperature for $10 \mathrm{~min}$. The $\mathrm{pH}$ ranged from 6 to 11 and the temperature ranged from 20 to $70{ }^{\circ} \mathrm{C}$. The buffers used were $\mathrm{K}_{2} \mathrm{HPO}_{4}-\mathrm{KH}_{2} \mathrm{PO}_{4}(\mathrm{pH}$ 6.0), Tris-acetate ( $\mathrm{pH} 7.0$ 8.0) and Glycine-NaOH (pH 9.0-11.0). The chloride ion 
was measured spectrophotometrically at $460 \mathrm{~nm}$ from the absorbance of colored ferric thiocyanate complex. One unit activity was defined as the amount of enzyme that was required to release $1 \mu \mathrm{mol}$ chloride ion per minute. The protein concentration of crude extract was determined using Bradford method and bovine serum albumin (BSA) as a reference (Bradford 1976).

\subsection{Bioinformatic analysis}

Three-dimensional structure prediction of protein was carried out using I-TASSER program (Zhang 2008). MolProbity program was used to validate of the stereochemistry of the structure (Chen et al. 2010).

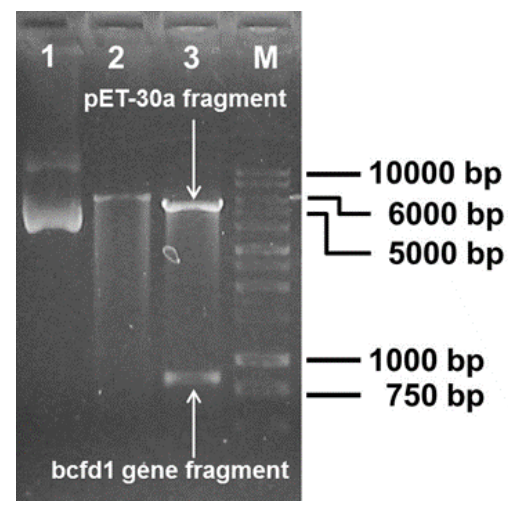

FIGURE 1 Confirmation of the $b c f d 1$ gene subcloning into pET$30 \mathrm{a}(+)$ by restriction analysis (M: $1 \mathrm{~kb}$ DNA Ladder, 1: non-digest pET-bcfd1, 2: HindIII digested pET-bcfd1, 3: HindIII and EcoRI digested pET-bcfd1).

\section{Results and discussion}

\subsection{Construction of pET-bcfd1 expression system}

The recombinant pET-bcfd1 obtained from pGEM-bcfd1 were size screened and digested with EcoRI and HindIII (Figure 1), confirmed by re-PCR and sequenced. Sequences analysis showed that $b c f d 1$ gene was integrated into expression vector pET-30a with the correct orientation and in frame with plasmid sequence (Figure 2). These analyses confirmed that the $b c f d 1$ gene has been successfully subcloned into pET-30a(+) expression vector.

\subsection{Expression of recombinant $p E T-b c f d 1$}

The SDS-PAGE analysis confirmed that recombinant Bcfd1 protein has been successfully expressed by pET$b c f d 1$ in E. coli BL21(DE3). The expression of the recombinant protein presence as prominent protein band with Mr about $37 \mathrm{kD}$ (Figure 3a). This size is greater than the molecular weight of Bcfd1 actually is but it is consistent with prior in silico prediction. Prior in silico analysis informed that the expressed recombinant protein has protein fusion on its $\mathrm{N}$ terminus, that is, 6xHis-tag and S-tag. This fusion made the molecular weight of protein increase than before, from $31.5 \mathrm{kD}$ to $37.1 \mathrm{kD}$. The overexpression of $b c f d 1$ gene still observable though IPTG concentration was lowered to $0,01 \mathrm{mM}$ (Figure $3 \mathrm{~b}$ ). This is of fortunate as low IPTG will increase soluble protein production (Pacheco et al. 2012), as indicated by the large amount of recombinant Bcfd1 in the cell lysate (Figure 3b).

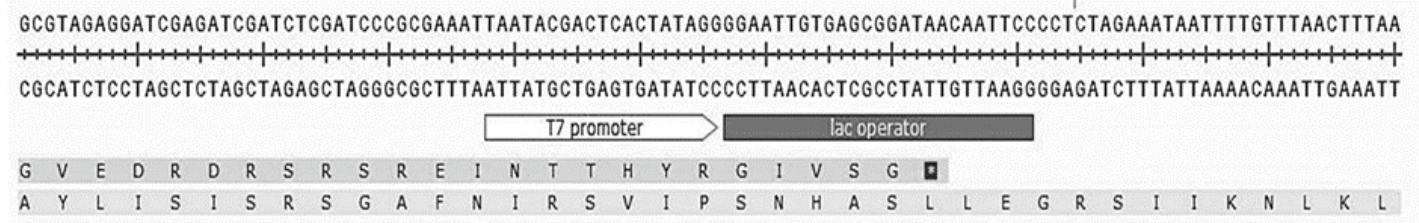

NdeI

GAAGGAGATATACATATGCACCATCATCATCATCATTCTTCTGGTCTGGTGCCACGCGGTTCTGGTATGAAAGAAACCGCTGCTGCTAAATTCGAACGCCAGCACATGGA

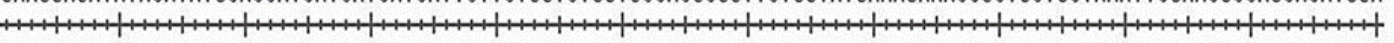
CTTCCTCTATATGTATAGGTGGTAGTAGTAGTAGTAAGAAGACCAGACCACGGTGCGCCAAGACCATACTITCTTTGGCGACGACGATTTAAGCTTGCGGTCGTGTACCT
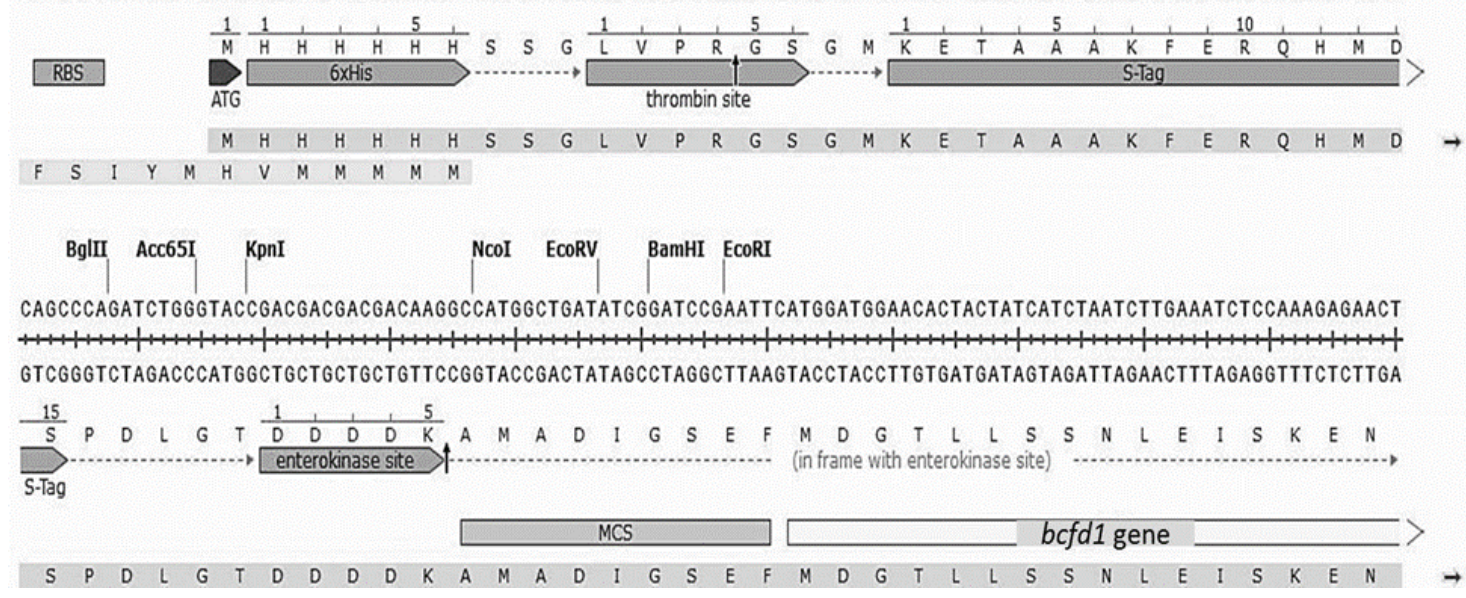

FIGURE 2 The orientation of the $b c f d 1$ gene in $p E T$ - $b c f d 1$ expression system. 


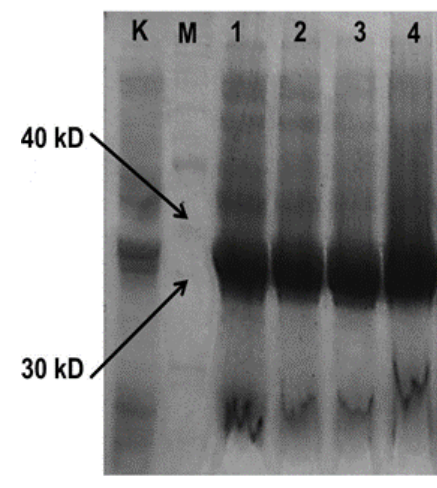

(a)

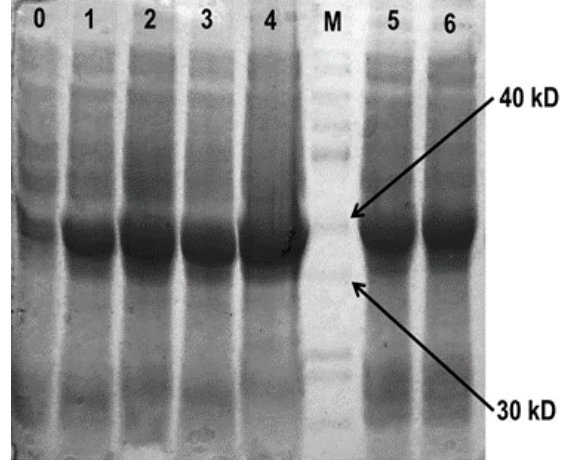

(b)

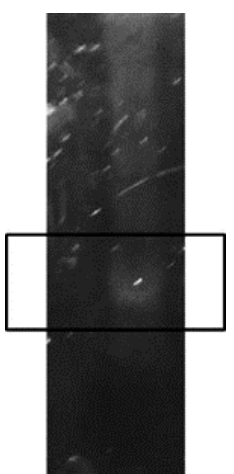

(c)

FIGURE 3 SDS-PAGE and native PAGE of the recombinant Bcfd1 expressed by pET-bcfd1. (a) Total protein cell analysis (M:protein ladder; K: E. coli BL21; 1-4: recombinant Bcfd1 expressed by pET-bcfd1 on 1-4 $\mathrm{h}$ after IPTG induction at $30^{\circ} \mathrm{C}$ ); (b) Total protein cell and crude extract analysis (M: protein ladder; 0-2: total protein cell on 0-2 $\mathrm{h}$ induced by $0.01 \mathrm{mM}$ IPTG; 3-4: total protein cell after 1-2 $\mathrm{h}$ on $0.1 \mathrm{mM}$ IPTG induction; 5-6: cell lysate on $2 \mathrm{~h}$ with $0.01 \mathrm{mM}$ and $0.1 \mathrm{mM} \mathrm{IPTG}$ induction at $30^{\circ} \mathrm{C}$ ); (c) Qualitative dehalogenase assay of the recombinant Bcfd1 protein on native PAGE.

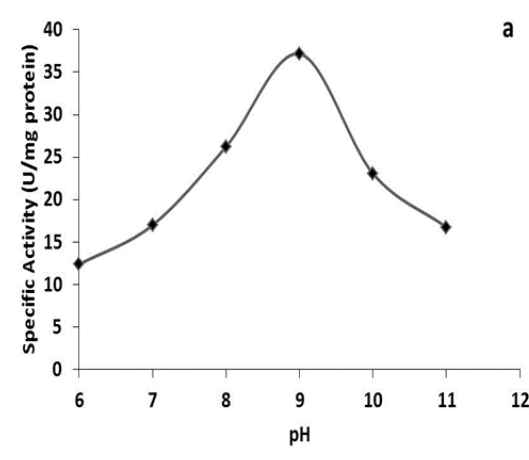

(a)

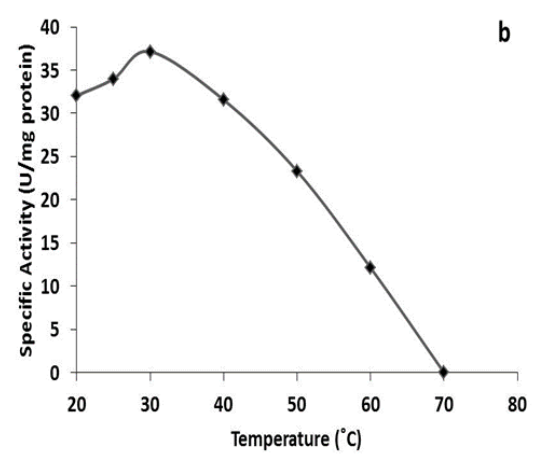

(b)

FIGURE 4 Dehalogenase activity of Bcfd1 at various $\mathrm{pH}$ (a) and temperature (b)

\subsection{Qualitative dehalogenase assay of recombinant Bcfd1}

The zymogram analysis suggested that recombinant Bcfd1 shows dehalogenase activity as indicated by $\mathrm{AgCl}$ formation on native PAGE (Figure 3c). Degradation of MCA by haloacid dehalogenase release chloride ion. The free chloride ion will react with a silver ion from $\mathrm{AgNO}_{3}$ solution to produce AgCl. The formation of $\mathrm{AgCl}$ was indicated by the presence of white precipitation on the gel.

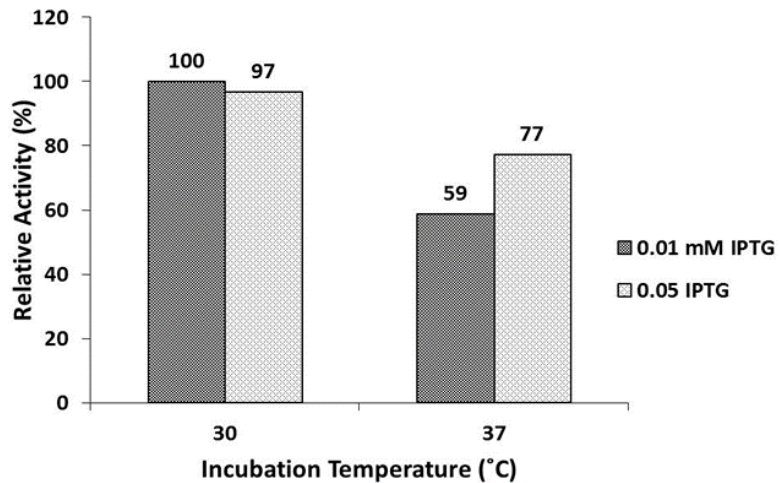

FIGURE 5 Effect of induction temperature and inducer concentration on recombinant Bcfd1 activity.

\subsection{Optimum $\mathrm{pH}$ and temperature of dehalogenase activity of recombinant $\mathrm{Bcfd} 1$}

Variation of $\mathrm{pH}$ and temperature indicated that recombinant $\mathrm{Bcfd} 1$ has its optimum activity at $\mathrm{pH} 9$ at $30^{\circ} \mathrm{C}$ (Figure 4), consistent with bacterial L-haloacid dehalogenase (Kurihara et al. 2000). At this pH, Asp8 (corresponds to Lhaloacid dehalogenase from Xhantobacterium autotropicus, DhlB) available in negative charges and attacks the substrate to release chloride ion (Ridder et al. 1997). It could be seen from Table 1 that the recombinant Bcfd1 dehalogenase has $37.14 \mathrm{U} / \mathrm{mg}$ specific activity that degraded $1.7 \%$ of $5 \mathrm{mM}$ MCA in $10 \mathrm{~min}$. This activity higher compared to wildtype dehalogenase obtained from B. cereus IndB1, which was only12 U/mg.

The optimum induced condition was obtained by 0.01 $\mathrm{mM}$ IPTG at $30^{\circ} \mathrm{C}$ (Figure 5). This result suggests that lower-temperature may form correct folding to produce an active enzyme (Schein and Noteborn 1988; Pacheco et al. 2012). As an addition, the low temperature also restricts activity some protease that can degrade target protein (Sahdev et al. 2007). 
TABLE 1 Activity of recombinant Bcfd1 dehalogenase against MCA.

\begin{tabular}{lllllll}
\hline $\mathrm{pH}$ & $\mathrm{Temp}\left({ }^{\circ} \mathrm{C}\right)$ & $\begin{array}{l}\text { Free } \mathrm{Cl}^{-} \\
(\mu \mathrm{mol})\end{array}$ & $\begin{array}{l}\text { Protein concen- } \\
\text { tration }(\mathrm{mg} / \mathrm{ml})\end{array}$ & Activity $(\mathrm{U} / \mathrm{ml})$ & $\begin{array}{l}\text { Specific activity } \\
(\mathrm{U} / \mathrm{mg})\end{array}$ & $\begin{array}{l}\text { Percent degra- } \\
\text { dation }(\%)\end{array}$ \\
\hline 9 & 30 & 85 & 4.58 & 170 & 37.14 & 1.70 \\
\hline
\end{tabular}

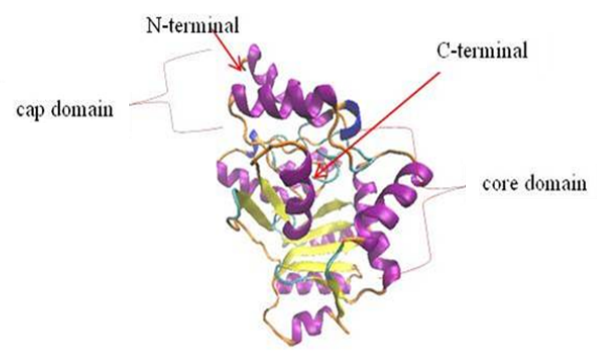

FIGURE 6 Tertiary structure prediction model of Bcfd1. Alpha helix: purple, beta sheet: yellow, turn: cyan, and coil: brown. Tertiary structure prediction carried out I-TASSER server, structure validation using MolProbity and structure visualization using VMD.

\subsection{Tertiary structure prediction of Bcfd1}

The structure prediction was based on the sequence of the full-length construct of the Bcfd1. The predicted tertiary structure of Bcfd1 was estimated has conserved $\alpha / \beta$ hydrolase folding motif for haloacid dehalogenase superfamily (Figure 6). This folding motif consists of two domains, named by cap domain and core domains. The active site was predicted located at the interface of two domains and composed by catalytic residues and binding residues (Novak et al. 2013).

\section{Conclusions}

Haloacid dehalogenase $b c f d 1$ gene from $B$. cereus IndB1 was successfully cloned into pET-30a(+) in E. coli BL21(DE3). Overexpression of Bcfd1 was obtained by $0.01 \mathrm{mM}$ IPTG induction on culture $\mathrm{OD}_{550} \approx 1.0$ for $2 \mathrm{~h}$ at $30^{\circ} \mathrm{C}$. On $5 \mathrm{mM} \mathrm{MCA}$, Bcfd1 has specific activity of $37.14 \mathrm{U} / \mathrm{mg}$ at $30^{\circ} \mathrm{C}, \mathrm{pH} 9$, with $1.70 \%$ degradation for $10 \mathrm{~min}$. The tertiary structure of Bcfd1 predicts the presence of conserved $\alpha / ß$ hydrolase folding motif, indicated that the Bcfd1 is closely related to haloacid dehalogenase superfamily.

\section{Acknowledgments}

The authors are grateful to Chemistry Department, Faculty of Mathematics and Natural Sciences, Institut Teknologi Bandung, Indonesia, and The Asahi Glass Foundation, Japan. This research was (partially) supported by the Asahi Glass Foundation.

\section{Authors' contributions}

ER designed the study. I carried out the laboratory work, analyzed the data and wrote the manuscript. Both authors read and approved the final version of the manuscript.

\section{Competing interests}

The authors declare no competing interest.

\section{References}

Arif F. 2013. Cloning and sequencing of haloacid dehalogenase gene from Bacillus cereus local strain. Bachelor thesis. [Bandung, Indonesia]: Institut Teknologi Bandung.

Bergmann JG, Sanik J. 1957. Determination of trace amounts of chlorine in naphtha. Anal Chem. 29(2):241-243. doi:10.1021/ac60122a018.

Bradford MM. 1976. A rapid and sensitive method for the quantitation of microgram quantities of protein utilizing the principle of protein-dye binding. Anal Biochem. 72(1):248-254. doi:10.1016/00032697(76)90527-3.

Chen VB, Arendall WB, Headd JJ, Keedy DA, Immormino RM, Kapral GJ, Murray LW, Richardson JS, Richardson DC. 2010. MolProbity: all-atom structure validation for macromolecular crystallography. Acta Crystallogr Sect D: Biol Crystallogr. 66(1):1221. doi:10.1107/S0907444909042073.

Choi JH, Keum KC, Lee SY. 2006. Production of recombinant proteins by high cell density culture of Escherichia coli. Chem Eng Sci. 61(3):876-885. doi:10.1016/j.ces.2005.03.031.

Cohen SN, Chang AC, Boyer HW, Helling RB. 1973. Construction of biologically functional bacterial plasmids in vitro. Proc Natl Acad Sci USA 70(11):3240-3244.

Hardman DJ, Slater JH. 1981. The dehalogenase complement of a soil pseudomonad grown in closed and open cultures on haloalkanoic acids. Microbiology 127(2):399-405. doi:10.1099/00221287-127-2-399.

Hill KE, Marchesi JR, Weightman AJ. 1999. Investigation of two evolutionarily unrelated halocarboxylic acid dehalogenase gene families. J Bacteriol. 181(8):25352547.

Huyop FZ, Yusn TY, Ismail M, Wahab RA, Cooper R. 2004. Overexpression and characterisation of nonstereospecific haloacid Dehalogenase E (DehE) of Rhizobium sp. Asia Pac J Mol Biol Biotechnol. 12(1 \& 2):15-20.

Kawasaki H, Tsuda K, Matsushita I, Tonomura K. 1992. Lack of homology between two haloacetate dehalogenase genes encoded on a plasmid from Moraxella sp. strain B. J Gen Microbiol. 138(7):1317-1323. doi:10.1099/00221287-138-7-1317.

Kurihara T, Esaki N, Soda K. 2000. Bacterial 2- 
haloacid dehalogenases: structures and reaction mechanisms. J Mol Catal B: Enzym. 10(1):57-65. doi:10.1016/S1381-1177(00)00108-9.

Liu JQ, Kurihara T, Hasan AK, Nardi-Dei V, Koshikawa H, Esaki N, Soda K. 1994. Purification and characterization of thermostable and nonthermostable 2haloacid dehalogenases with different stereospecificities from Pseudomonas sp. strain YL. Appl Environ Microbiol. 60(7):2389-2393.

Maier RM, Pepper IL, Gerba CP. 2009. Environmental Microbiology. San Diego (California): Academic Press. Google-Books-ID: A2zL8YBXQfoC.

Novak HR, Sayer C, Panning J, Littlechild JA. 2013. Characterisation of an L-haloacid dehalogenase from the marine psychrophile Psychromonas ingrahamii with potential industrial application. Mar Biotechnol. 15(6):695-705. doi:10.1007/s10126-013-9522-3.

Olaniran A, Pillay D, Pillay B. 2004. Haloalkane and haloacid dehalogenases from aerobic bacterial isolates indigenous to contaminated sites in Africa demonstrate diverse substrate specificities. Chemosphere 55(1):27-33. doi:10.1016/j.chemosphere.2003.10.067.

Pacheco B, Crombet L, Loppnau P, Cossar D. 2012. A screening strategy for heterologous protein expression in Escherichia coli with the highest return of investment. Protein Expression Purif. 81(1):33-41. doi:10.1016/j.pep.2011.08.030.

Ridder IS, Rozeboom HJ, Kalk KH, Janssen DB, Dijkstra BW. 1997. Three-dimensional structure of 1-2haloacid dehalogenase from Xanthobacter autotrophicus GJ10 complexed with the substrate-analogue formate. J Biol Chem. 272(52):33015-33022. doi:10.1074/jbc.272.52.33015.

Römpp A, Klemm O, Fricke W, Frank H. 2001. Haloacetates in fog and rain. Environ Sci Technol. 35(7):1294-1298.

Sahdev S, Khattar SK, Saini KS. 2007. Production of active eukaryotic proteins through bacterial expression systems: a review of the existing biotechnology strategies. Mol Cell Biochem. 307(1-2):249-264. doi:10.1007/s11010-007-9603-6.

Schein CH, Noteborn MHM. 1988. Formation of soluble recombinant proteins in Escherichia coli is favored by lower growth temperature. Nat Biotechnol. 6(3):291294. doi:10.1038/nbt0388-291.

Torz M, Beschkov V. 2005. Biodegradation of monochloroacetic acid used as a sole carbon and energy source by Xanthobacter autotrophicus GJ10 strain in batch and continuous culture. Biodegradation 16(5):423-433. doi:10.1007/s10532-004-3614-8.

Tsang JSH, Sam L. 1999. Cloning and characterization of a cryptic haloacid dehalogenase from Burkholderia cepacia MBA4. J Bacteriol. 181(19):6003-6009.

Zhang Y. 2008. I-TASSER server for protein 3D structure prediction. BMC Bioinf. 9(1):40. doi:10.1186/14712105-9-40. 